Boise State University

ScholarWorks

Political Science Faculty Publications and

Presentations

Department of Political Science

$1-1-2016$

\title{
The Benefits of Balance: Credibility, the Rule of Law, and Investment in Latin America
}

Michael Touchton

Boise State University 


\title{
THE BENEFITS OF BALANCE \\ Credibility, the Rule of Law, and Investment in Latin America
}

\author{
Michael Touchton \\ Boise State University
}

\begin{abstract}
Research surrounding political institutions and credible commitment to the rule of law is integral to recent efforts to tie democracy to economic development. I identify the determinants of rule-of-law perceptions in Latin America and argue that constraining elected officials facilitates a commitment to democracy that makes government policies credible. I also argue that aspects of politics leading to deadlock might have a hidden upside in generating policy credibility. I test my arguments against pooled cross-sectional, time series data for twenty Latin American countries between 1996 and 2012. Ultimately, my research demonstrates the benefits of functioning checks and balances among elected officials for the rule of law and provides a uniform framework linking democratic inputs to legal and economic outcomes.
\end{abstract}

Latin American countries have had difficulty committing to the rule of law. Scholars blame the (un)rule of law for low investment, slow economic growth, and stagnant or unequal political development (see Méndez O'Donnell; Pinheiro 1999; North and Weingast 1989; De Soto 2003; O'Donnell 2001; Mainwaring and Scully 2010; Diamond 1999; Foweraker and Krznaric 2002; Haggard, MacIntyre, and Tiede 2008; Haggard and Tiede 2011). From an economic standpoint, governments' abilities to commit credibly to policy regimes and the rule of law also allows governments to commit to protecting property rights, enforcing contracts, and treating firms and investors equitably under the law..$^{1}$ Investors are justifiably reluctant to invest if a government cannot credibly guarantee that their investments will be safe from expropriation. Firms will not invest the extensive capital necessary to buy land or build a factory if they fear that the state will nationalize their investment once it becomes profitable (see Haber, Razo, and Maurer 2003; Hoff and Stiglitz 2002; North and Weingast 1989). Furthermore, investors will not keep their money in a given country if they fear that the government will tax profits at exorbitant rates. Investment capital therefore flows away from countries where profits are in jeopardy and toward countries where profits are safe from rapacious governments. Ultimately, markets fail to develop and growth suffers in countries where governments cannot make a credible commitment to uphold property rights and enforce contracts.

\footnotetext{
This manuscript was accepted for publication in September 2015. New data have become available on several key variables. The updated data set and Stata do-file for replication are available on the author's website: http://sps.boisestate.edu/politicalscience/faculty/mike-touchton/.

1. Institutional economists have made a cottage industry from these assertions (see North and Weingast 1989; De Soto 2003; Keefer and Stasavage 2003; Glaeser et al. 2004; see also Coase 1960; Demsetz 1967).
} 
There is considerable discussion of what the rule of law means, and some scholars argue that the term is so amorphous and contested that it has become meaningless (see Weingast 1997; Tamanaha 2004; Munck 2009). I use a thin economic definition from Hoff and Stiglitz (2002) as a point of departure: for the purposes of this study, the rule of law exists when a country features "well-defined and enforced property rights, broad access to those rights, and predictable rules for resolving property rights disputes" (1). Furthermore, "under the 'rule of law,' the ability of the local, regional, and national authorities to take arbitrary actions is circumscribed" (2). I add policy credibility to complete my definition: observers must be confident that agents of the state will implement and enforce legislation for the rule of law to exist.

I emphasize the economic aspects of the rule of law, but the concept is important from a political standpoint as well. For instance, many scholars argue that the rule of law is part and parcel of consolidated democracy. Political institutions will not function as intended without the rule of law as a strong foundation. For example, elections will not be free or fair (O'Donnell 2004), political rights and civil liberties will not be enforced, and politicians who violate the law will not be held accountable (Diamond 1996; Maravall and Przeworski 2003; Weingast 1997) in the rule of law's absence.

Growing evidence demonstrates the rule of law's importance for political and economic development, yet we know relatively little about how the rule of law comes to exist in the first place. ${ }^{2}$ There are many useful theoretical frameworkssuch as those in Weingast (1997), Maravall and Przeworski (2003), Méndez, O'Donnell, and Pinheiro (1999) and O'Donnell (2001, 2004)-but relatively few empirical tests of these arguments that incorporate differences across countries or changes over time within countries. ${ }^{3}$ I fill gaps in theoretical and empirical knowledge on the connections between political inputs and economic outcomes by taking a step back and identifying the determinants of perceptions of the rule of law in Latin America. My study is limited to a measure of perceived rule of law, but perceptions are important: investors make decisions on the basis of their perceptions, which may or may not reflect all investors' experience with government. Investors face time constraints and barriers to collecting information on all property rights disputes or all contract law rulings. However, it is quick and therefore attractive to evaluate government credibility on the basis of general, rather than specific, political and economic analysis. I argue that the presence of opposition politicians in veto-player institutional positions increases the costs of altering policy and ultimately the credibility of a government's policy commitment. Second, I test my theoretical argument along with other popular theories against panel data encompassing twenty Latin American countries from 1996 to 2012. Finally, I address the connection between perceptual governance measures

2. Some exceptions are Acemoglu Johnson, and Robinson (2001), Woodberry (2012), Nunn (2008), and Charron (2009).

3. Chavez (2004) and Miller and Perito (2004) provide extensive arguments chronicling the rule of law in individual countries. Some recent cross-national efforts to study the rule of law include Haggard and Tiede (2011) and Touchton (2014, 2015). 
and investors' actions by estimating a model of gross fixed capital formation (fixed investments) in Latin America using similar independent variables.

I limit my data set to Latin American countries for three central reasons. First, Latin American countries' colonial origins are relatively similar to countries in other regions. Acemoglu, Johnson, and Robinson (2001) show the relevance of colonial origins for institutional performance and economic growth, but colonial origins can confound efforts to model the rule of law or investment using contemporary political variables. Limiting my study to Latin American countries lets me hold colonial origins relatively constant and avoid such barriers to appropriate estimation. Second, Latin American countries have a longer history with democracy than countries in other developing regions. The longer experience with democracy allows for a potentially more appropriate test of democratic political arguments than elsewhere because Latin American countries have had a longer time to consolidate democracy following third-wave transitions than other regions such as Africa or Southeast Asia.

The results of my analysis show that political and institutional constraints on elected officials have a statistically significant impact on rule-of-law perceptions. Specifically, I argue that politicians are more likely to exercise veto authority and protect the rule of law when they are not members of the majority party. Rather than only creating deadlocked situations, I contend that the inability to pass policy-changing legislation has a hidden upside for commitment to a given policy regime in general and to perceptions of the rule of law in particular. Perceptions of the rule of law improve as the ideological gap between politicians in different branches of government grows, even after controlling for factors thought to influence citizens' ratings of the rule of law, such as the level of wealth within a country and the level of ethnolinguistic fractionalization. This result suggests that previous arguments surrounding the perils of polarization, such as those found in Linz (1994) or Ames (2009), may have been premature: the factors thought to undermine government policy by paralyzing the legislative process may be the same factors generating credible commitments to important policies in other areas. My research thus provides a new direction for scholarship on politics, credibility, and economic development in Latin America.

\section{THEORY}

There is a broad consensus that perceptions of the rule of law influence both political and economic development (North and Weingast 1989; Weingast 1997; O'Donnell 2001, 2004; De Soto 2003; Maravall and Przeworski 2003). This begs an important question: What determines perceptions of the rule of law in the first place? Previous research identifies political institutions as relevant for the rule of law. For example, scholars identify electoral rules, regime type, interaction between branches of government, number of bottlenecks in the policy-making process (veto points), and federalism as elements potentially bringing accountability to government and thus protecting private rights (Kunicová and Rose-Ackerman 2005; Persson and Tabellini 2003; Lijphart 1999). Political institutions may be an important part of the explanation, but it can be difficult to disentangle myriad 
institutional elements and the endogeneity problems that their evolution generates (Acemoglu, Johnson, and Robinson 2001). Furthermore, institutional structures alone do not generate policy. Instead, individual politicians facing partisan pressure channel constituent interests through representative institutions. Ignoring these agents' roles as institutional gatekeepers renders previous research incomplete. Institutions will not function as intended unless it is in the political interests of elected officials to exercise their authority and guarantee government respect for private rights. Both foreign and domestic investors key in on this area when assessing the rule of law because institutional talk is cheap: investors want to know not only whether institutions offer politicians the opportunity to constrain one another and protect investors' rights but also whether politicians have the motive to do so as well.

Tsebelis (2002) provides the theoretical justification for considering not only the structure of institutional checks and balances but also the preferences of politicians, and thus their incentives within those institutions. Tsebelis argues that three critical elements determine the importance of veto points that can derail policy change within institutions: the number of veto points, the coherence of opposition veto players, and the ideological distance between the veto players and the executive. Tsebelis discusses how these elements make de jure veto points fully operational: increasing the number of veto points and the ideological distance between veto players increases the difficulty in altering policy from the status quo.

I argue that politicians must have incentives to exercise the checks and balances of their offices in order to credibly commit to the rule of law. Explanations focusing on constitutional structures, such as those in Persson and Tabellini (2003), describe only one part of the story on credibility; understanding the role of politicians within political institutions is essential to understanding credible commitment. Borrowing from Tsebelis's $(1995,2002)$ and Brown, Touchton, and Whitford's (2011) logic, I argue that pluralism among elected officials alters investors' expectations of how political incentives influence executive-legislative relations and subsequent commitments to the rule of law. Politicians from parties with similar policy preferences in the executive and legislative branches of government have few incentives to block one another's policies because they are likely to share similar views on what makes for good policies in the first place. Furthermore, politicians from parties with similar policy orientations are likely to work together in the future to enact their preferred policies. Thwarting one another in the present decreases the prospect for future collaboration to achieve mutually desirable goals because it erodes trust between parties and increases the risk of negative retaliation against future proposals. Politicians from parties with similar policy preferences therefore do not have incentives to prevent one another from violating the rule of law, which in turn renders checks and balances between the executive and legislature impotent when members of these parties occupy both branches of government. As a result I do not expect politicians from parties with similar policy preferences to exercise vetoes and block one another's policies as frequently as would politicians with divergent preferences. It is important to note the probabilistic nature of my argument. I do not intend to suggest that there are no incentives for similar parties to block one another-only that incen- 
tives to block one another generally increase along with the ideological distance between parties. For instance, Mexico's Partido Revolucionario Institucional (PRI) and Partido Acción Nacional (PAN) may very well block one another, but I expect this to occur less often than for the PAN and the Partido Revolucionario Democrático (PRD).

Several empirical studies both directly and indirectly support my reasoning on institutions, their occupants, and credibility. Keefer and Stasavage (2003) argue that strong differences among the preferences of veto players in the government bolster the institutions underpinning checks and balances: the greater the ideological distance between elected officials, the greater the impact that checks and balances have on policy outcomes. Stasavage (2002) identifies the importance of partisan interests for generating commitments to repay state debt amid numerous veto players. Frye (2002) showcases the role of agents within the court system as well as those enforcing bureaucratic regulations in securing property rights in Russia. Finally, Ugalde (2000) identifies the dramatic improvement in oversight of the executive branch as ideological pluralism increases in Mexico's legislature. The result is increased oversight through incentives to oppose rather than appease the executive branch and a break with the country's institutional collusion of the past.

In general, policy credibility is the key factor in many analyses of what creates commitments to investors' rights, including property rights and contract enforcement (North 1990; North and Weingast 1989; Henisz 2000, 2002; Henisz and Zelner 2007; Keefer 2004; Keefer and Knack 2002; Hicken, Satyanath, and Sergenti 2005; Andrews and Montinola 2004). In these studies (and many others) investors privilege the government that can do relatively less harm, given political constraints, over the government that has the relative freedom to help but also to hinder investment. The incentives pushing politicians to work together or to oppose one another are therefore important for investors because they generate expectations about how democratic institutions actually work-not how they are supposed to work. I contend that investors witnessing politicians' commitments to the rule of law assess the credibility of these commitments by determining whether politicians have incentives to honor their promises. Simply put, investors deem commitments to the rule of law more credible as politicians' costs of reneging on these commitments increase. My logic here is not new-James Madison presented it in 1788 in the Federalist Papers, No. 51—and Douglass North (1990), Barry Weingast (1997), and many others have argued for the utility of making unilateral policy change difficult. However, effective political constraints do not just prevent policy change: low policy volatility may benefit investors in and of itself, but the presence of political constraints also brings accountability to governance. Opposition politicians have fewer incentives to collude in corrupt activities than do politicians in the same party or those with a similar ideology. Furthermore, politicians have incentives to report corruption and hold the violators accountable if they represent another party or ideology. I contend that this argument is just as applicable for the rule of law as for corruption. This is not to say that politicians who disagree with one another always prefer to respect the rule of law-far from it. My argument is only that politicians who disagree have incentives to prevent 
the passage of one another's policies, including those that violate the rule of law. In turn, investors will deem the rule of law relatively more protected under such political configurations than in circumstances in which politicians lack similar incentives, all things being equal.

\section{THE RULE OF LAW IN LATIN AMERICA}

Purely structural aspects of political institutions thought to be relevant for economic development-such as the constitutional separation of powers or checks and balances in Persson and Tabellini (2003), or the origin of a country's legal system in La Porta, López-de-Silanes, and Shleifer (2008) and Djankov and colleagues (2002) — offer poor explanations for the wide variation in rule-of-law perceptions across Latin America's diverse political contexts. Many Latin American constitutions are quite similar to one another in terms of separate executive and legislative branches of government in a representative democratic framework, separate judiciaries, civil law legal systems, and some combination of proportional representation and single-member-plurality rules translating votes into seats. Of course, there are also large, visible differences in the level of institutional performance in Latin America-dating to the colonial era in many countries-as discussed in Acemoglu, Johnson, and Robinson (2001). Variation in rule-of-law scores effectively reflects these differences in general institutional performanceit would surprise no one to find that broad measures of institutional quality are statistically connected to perceptions of the rule of law. In contrast, the relative ease or difficulty with which elected policy makers can pass legislation varies from year to year and country to country in the sample, given the configurations of elected officials, their party allegiance, and their interests at a given time. These elements of democratic political life are not mirror images of the rule of law itself, and certainly not its components of property rights and contract enforcement. It is therefore possible and potentially fruitful to estimate the impact of political constraints on government on the rule of law.

Previous research has found that credible commitments arise from political institutions and constitutional rules that limit arbitrary power, bring accountability to government, and constrain politicians' behavior in wealthy democracies (North and Weingast 1989; Tsebelis 2002; Weingast 1997; Barro and Gordon 1983). Yet Latin American countries have adopted democratic constitutions and political institutions similar in form to those in wealthy democracies with little success; translated institutions and rules rarely function as advertised in these cases (Méndez, O’Donnell, and Pinheiro 1999; O’Donnell 2001). Illiberal democracies that have developed in the region have the trappings of democratic institutions but place no real limits on politicians' power (Zakaria 2007). These countries imitate the form of a credible government but miss out on the function: they treat citizens inequitably under the law, continue to seize property, and confiscate investment profits rendering incredible any of their claims to support the rule of law.

Venezuela's recent history illustrates how many Latin American institutions have liberal democratic forms but illiberal functions. For example, Venezuela's constitution separates powers and endows each branch of government with the 
theoretical ability to exercise checks and balances against the other branches. However, Hugo Chávez and his party, the Partido Socialista Unido de Venezuela (PSUV), governed Venezuela without a strong, organized opposition among elected officials to constrain them in the early part of the twenty-first century. The Chávez administration's policies generated regular disputes over investors' rights, and private-sector investment fled the country during his administration (Garay and González 2008; Stein 2011). PSUV members of the National Assembly were disinclined to challenge former president Hugo Chávez's actions during his tenure because political advancement theoretically depended on pleasing him and his party, the PSUV, which dominated the institution. This dynamic continues under current president Nicolás Maduro. President Maduro's policy commitments, including any promises to the refrain from future violations of investors' rights, are thus not credible, because few other elected officials in positions of veto authority have incentives to constrain him. But suppose we could remove members of President Maduro's far-left PSUV from the National Assembly and repopulate the chamber with members of one of the parties opposed to Maduro's policies, Un Nuevo Tiempo (UNT), whose policy preferences are center-left. This new National Assembly might be more likely to block Maduro's far-left policies in some areas because of the UNT politicians' centrist positions on many policy issues. Yet any new Venezuelan commitment to protect investors' rights would only be somewhat more credible than under PSUV dominance of the presidency and the legislature, because members of the far-left PSUV and the center-left New Era coalition still agree fundamentally on many policies-potentially including nationalization or high taxation of private property. Now suppose we could repopulate the National Assembly with the center-right, pro-business Primero Justicia (PJ) party that oppose all of Maduro's preferences to nationalize private property. ${ }^{4}$ Investors might then be more confident that Venezuela's institutional checks and balances would become operational. Venezuela's commitment to the economics of the rule of law would be relatively more credible in this scenario because PJ members would have incentives to oppose Maduro. PJ politicians disagree fundamentally with Maduro's policies and would not likely work with him on future legislation. This party's opposition to the executive's policy preferences would thus send signals to investors that their rights would be more likely to be protected than under circumstances in which a single party governs the country or several ideologically similar parties occupy the National Assembly.

Left-leaning parties' commitment to property rights and contract enforcement may be entirely credible, but the parties may suffer from perceptual bias: many observers, especially investors, may simply trust right-wing parties' commitments to pro-business policies more. In this sense, a left-leaning party's commitment not to violate property rights would become more credible in investors' eyes when politicians with incentives to oppose violations of property rights are present in office. This reflects James Madison's sentiments in the Federalist No. 51, where "ambition must be made to counteract ambition" to achieve successful gov-

4. Venezuela's opposition coalition, Mesa de la Unidad Democrática, had recently won a supermajority in the National Assembly as this article went to press. 
ernance. The Venezuelan example also shows how purely constitutional separation of powers and checks and balances alone do not generate credible commitment to the rule of law. The investing public simply cannot trust the politicians in these institutions to constrain one another and protect investors' rights when the majority belongs to the president's party.

In this vein, I argue that investors are no fools and want to see evidence of government commitments to protect property rights and enforce contracts before they make investments. As a result, I hypothesize that investors gather information on concrete events as opposed to more abstract concepts, such as the wording of a constitutional clause, when evaluating institutional performance and a government's policy commitments. For instance, investors want to know whether presidents actually veto legislation nationalizing private property rather than whether the constitution allows for a veto in the first place. The political incentives for politicians in the legislative and executive branches of government to constrain one another and countries' experience with outcomes in this area thus indicate how well institutions actually work in practice. In this way, I capture the messiness of democratic politics by providing a realistic model of how visible outcomes of democratic practice can make or break a commitment to the rule of law.

The messiness of democracy may cut both ways: it is entirely possible that the political configurations most conducive to policy stasis, and thus commitment, could generate political and economic difficulties through deadlock. Deadlock is a dirty word in Latin American politics: scholars blame governments' inability to pass legislation for all manner of ills, from economic stagnation to military coups, dictatorship, and the failure to consolidate democracy in the region (Cheibub 2002; Linz 1994; Ames 2009; Mainwaring 1993). Deadlock among elected officials, the story goes, paralyzes policy makers and renders the government incapable of responding to new challenges and opportunities. The result is inefficient, unwieldy governance that lags behind the market and undermines a country's economic growth prospects. I have no quarrel with this view of deadlock but evaluate empirically whether the institutional and political factors thought to increase the risk of deadlock by constraining elected officials and undermining cooperation might also generate benefits in other areas, such as commitment to property rights and contract enforcement.

The following section describes the variables and methodology I use to estimate the influence of political institutions, their occupants, and socioeconomic variables on the rule of law in Latin America.

\section{VARIABLES AND METHODOLOGY}

I use a cross-national indicator from the World Bank's (2015) Governance Matters database to measure the rule of law in Latin America. ${ }^{5}$ The measure reflects aggregated responses to survey questions regarding country experts' and risk analysts' experience with contract enforcement, protection of property rights, le-

5. The World Bank's World Governance Indicators data are available at http://info.worldbank.org/ governance/wgi/index.aspx\#home. 
gal equality, the judicial system-even the police. The Worldwide Governance Indicators (WGI) project compiles material from thirty-one different surveys and polls, such as Afrobarometer, Freedom House, Gallup International, the US State Department, and so on (Kaufmann, Kraay, and Zoido-Lobatón 1999; Kaufmann, Kraay, and Mastruzzi 2012). The WGI then generates a variable, the rule of law, consisting of a weighted average for survey responses on property rights, contract enforcement, legal equality, and prevalence of crime. The surveys result in an aggregate measure covering an average of 182 countries at two-year intervals between 1996 and 2002 and annually through 2014. The cross-national breadth, temporal depth, and sophistication of the measure demonstrate why the WGI indicator is one of the most frequently employed governance measures worldwide (Kaufmann, Kraay, and Mastruzzi 2007c). Rule-of-law scores range from -2.31 (no rule of law) to +2.36 (perfect rule of law) and are scaled to a zero mean and a constant standard deviation (SD) for each year of data. ${ }^{6}$ Scores vary dramatically from one region to the next. Europe has the highest mean score at 1.65 while Africa has the lowest at -1.43 . Latin America's mean score is -0.61 . Chile has the highest mean score in the region, at 1.26, while Haiti has the lowest at -1.48 . There are 280 total observations among Latin American countries in the data set for this article.

\section{Independent Variables: Political Constraints}

My primary independent variable stems from Witold Henisz's (2000) efforts to create a cross-national measure of political constraints on government. Henisz's Political Constraint Index (POLCON) measures the extent to which any individual actor is limited in pursuing his or her preferred policies by the structure of a country's political institutions and the inferred preferences of politicians occupying those institutions. The first step in constructing the measure identifies the number of purely institutional, de jure veto points in a country's political system. Specifically, Henisz uses the Polity database (Marshall, Jaggers, and Gurr 2002) to identify the number of independent branches of government (executive, lower and upper houses of a legislature, judiciary, and any subnational entities) with theoretical veto power over policy making in a given country. Then Henisz codes data on the political parties in the system and their distribution within an independent executive and the legislative branch of government. The next step is an assessment of the relative alignment of political parties represented by politicians in these branches. The level of political constraints increases with each de jure veto point whose majority inhabitants are not members of the executive's political party. For example, a year in which a country features independent executive as well as lower and upper legislative chambers in complete political

6. A full discussion of the World Governance Indicators and their critics includes Kaufmann, Kraay, and Mastruzzi (2007a, 2007b, 2007c) and Kurtz and Shrank (2007a, 2007b).

7. Presidential systems, by construction, do have an additional de jure veto point compared to parliamentary systems. However, this is of no concern for my data, because all the Latin American countries in my data set use presidential systems of government (with Haiti as a slight exception) and there is wide variation in POLCON scores among these countries. 
alignment receives a score of 0 . Removing the political alignment in one chamber increases the constraint score for that country-year to 0.33 , two chambers to 0.66 , and all three to 1 (indicating maximum political constraints). Finally, Henisz evaluates the relative concentration of parties in each branch of the legislature. He includes the relative heterogeneity of political parties represented in the legislature in the measure because he deems policy change relatively more difficult when more interests must be satisfied in order to gain passage of any given legislation. Greater legislative fractionalization thus increases the costs of legislative and executive action, which decreases its feasibility. Henisz multiplies the level of legislative fractionalization by the previous institutions and political alignment score to calculate the final political constraints value. For instance, a country-year with an independent executive as well as lower and upper legislative chambers without alignment across them has an initial score of 1.0. A fractionalization score of 0.9 reflects a very high probability that two randomly drawn legislators will represent different parties. Multiplying 1.0 by 0.90 gives a POLCON score of 0.90 . The final measure is coded by country-year and exhibits continuous values ranging from 0 (least constrained) to 1 (most constrained). However, no country-year score exceeds 0.73 in the data. The mean score for Latin American countries in my data set is 0.31 and the standard deviation is 0.12 . Chile has the highest mean score, at 0.54 (most constrained), and Cuba has the lowest mean score (least constrained), at 0.00 . The mean score of the United States is 0.40 .

\section{Democracy}

Democratization increases the number of veto players through political competition, places institutional constraints on the chief executive, and increases citizen participation through elections. Kunicová and Rose-Ackerman (2005) argue that participation, political competition, and constraints on the chief executive all increase accountability as the population is better able to monitor politicians and identify corruption. Competition in democracies also produces accountability because it creates incentives for politicians to identify one another's corrupt behavior. Additionally, democracy improves public goods provision relative to authoritarian governance. Olken (2008) and Keefer and Khemani (2005) argue that greater public goods provision reflects greater cooperation and higher levels of the rule of law in democracies. I therefore evaluate whether relationships between democracy and the rule of law emulate those concerning corruption and the provision of public goods.

In contrast to democratic governments, authoritarian governments are likely to undermine the rule of law (Maravall and Przeworski 2003), as are illiberal democracies (Zakaria 2007). However, high economic growth under authoritarian regimes in some East Asian and a few Latin American countries suggests that these governments may have identified ways to make credible commitments to property rights and contract enforcement without democratic constraints on authority (Gehlbach and Keefer 2011; Montinola, Qian, and Weingast 1995; Knack and Keefer 1995; Barros 2003). Yet the countries in my data set receiving the least democratic scores on Freedom House's (FH) Political Rights indicator (Cuba, 
Haiti, Venezuela) are the ones exhibiting some of the lowest economic growth during the time frame my data set covers. This suggests that authoritarian governments are in no way better suited to protect investors than their democratic counterparts-quite the opposite, judging by these examples. Still, the question of whether democratic practice maps onto the rule of law is worth revisiting in the Latin American context to assess how well democratic theory matches political realities in the region.

Contemporary Latin America features primarily democratic governments, albeit illiberal ones in many cases. There is therefore wide variation among the quality of democracy in Latin America, which I capture through the Freedom House (FH) political rights score. Freedom House assesses political rights in each country around the world by collecting data on its electoral process, its levels of political participation and pluralism, and how well its government functions. Freedom House (2013) ranks each country from 1 to 7 on the basis of expert responses to ten different questions. This is a widely used measure of de facto, rather than de jure, democracy and allows me to evaluate further my argument surrounding institutional function over form. The mean score for the countries in my data set is 3.6, with a standard deviation of 1.4. Cuba exhibits the highest mean score (least free), at 7.0, and Costa Rica and Uruguay exhibit the lowest mean scores (most free), at 1.0.

\section{Party Orientation}

The party orientation variable measures the ideological orientation of the chief executive's party in each country and classifies it as left, right, or center. The conventional wisdom suggests that right-wing parties, with pro-business reputations in many cases, will enforce contracts in favor of the private sector more consistently and have greater respect for private property than left-wing parties to please their private-sector allies. For instance, many may believe that rightwing parties will keep their promises on the economic aspects of the rule of law in order to support their business constituencies, whereas left-wing parties will not-even if the right-wing parties are no more credible than the left-wing parties in other areas. Furthermore, right-wing parties have a reputation for supporting law and order in general, at least from a rhetorical standpoint. The private sector's presumed identification of the rule of law with the political right implies that increasing political constraints on the executive, increasing the effectiveness of institutional checks and balances, or increasing the ideological distance between elected officials in different branches of government may improve perceived rule of law when pro-business, right-wing parties are in opposition but undermine it when the right is in power.

The prospect that the business community in Latin America systematically trusts right-wing governments with their property rights more than left-wing governments deserves further attention. I therefore include a variable for rightwing governments in my statistical model to determine whether the conventional wisdom stands up to empirical scrutiny and to test whether the rule of law increases when right-wing governments are in office, all things being equal. I use 
Keefer and Stasavage's (2003) common measure of party orientation to examine this prospect. This indicator has been used extensively and is highly correlated with other measures of partisan policy orientation, such as those from Benoit and Laver (2006) (0.92) and the Comparative Manifesto Project (0.87) (Budge 2001; Klingemann et al. 2006). I recode the variable for ease of interpretation resulting in scores of 0,1 , or 2 to reflect the party of the chief executive's ideological positions as leftist, centrist, or right-wing. The mean is 0.61 and the standard deviation is 0.85. For 2012 Argentina and the Kirchner administration receive a score of 0 , the Piñera administration in Chile receives a 1, and the Calderón administration in Mexico receives a 2.

\section{Log of Per Capita Gross Domestic Product Adjusted for Purchasing Power Parity}

I also estimate the relationship between the rule of law and a country's wealth. A country's relative wealth is a key alternative explanation connecting highfunctioning democracies with the rule of law, namely, that any connections between industrialized democracies and the rule of law only reflect underlying links between these countries' wealth and their support for property rights and contract enforcement. A country's wealth could affect the rule of law, and vice versa, in several ways. For instance, previous research shows that low-income countries have a greater incidence of corruption than high-income countries (Treisman 2000). Bureaucrats in developing societies receive salaries that are sufficiently low to entice corrupt behavior. Low-income societies may also lack the institutions for detecting public malfeasance-thus, poorer countries tend to experience more corruption. In many ways, this variable helps test a broader modernization thesis that economic growth will improve the quality of institutions, governance, and democracy (Lipset 1959; Przeworski 2000; Boix 2011). I follow this scholarship and expect poorer countries to exhibit relatively lower rule-of-law scores than wealthier countries.

The variable I use records each state's per capita gross domestic product (GDP), adjusted for purchasing power parity (PPP), for each year in the database. These figures are in 2007 dollars and come from the World Bank's (2015) World Development Indicators. ${ }^{8}$

\section{Ethnolinguistic Fractionalization}

Recent research has emphasized the negative influence of ethnic heterogeneity in fostering growth and cooperation in society and the rule of law. For example, Easterly and Levine (1997) tie ethnolinguistic fractionalization (EF) to slow economic development, low income, and inequitable distribution of wealth. Campos, Saleh, and Kuzeyev (2011) connect high levels of ethnic fractionalization to low levels of economic growth (see also Schüler and Weisbrod 2010). Additionally, Habyarimana and colleagues (2007) describe how EF undermines the provision

8. I take the base $10 \log$ of each observation and transform the variable so that it conforms to assumptions of normality for use in my regression models. 
of public goods, La Porta and colleagues (1999) show how high EF is associated with low quality of governance, and Knack and Keefer (1997) tie EF to low social trust in many countries. Finally, Cerqueti, Coppier, and Piga (2012) identify a relationship between high levels of fractionalization and high levels of corruption, and Touchton (2013) connects EF directly to perceived rule of law. In many cases, EF's influence stems from the assertion that in-group and out-group members receive different treatment from public officials, private entrepreneurs, and society in general. It is not the law that governs the norms of behavior in such interactions, but ethnic, religious, linguistic, and/or clan loyalties that undermine some and empower others depending on membership in an in-group or out-group for a given circumstance.

Ethnic fractionalization is also important to include as a control variable because perceptions of the rule of law probably do not only arise from the political institutions identified in the literature as important. Instead, any factors that alter the public's perceptions of governance are also likely to be relevant (Barro and Gordon 1983; Mauro 1995). From this perspective, aspects of ethnic diversity, linguistic cleavages, and religious schisms may alter perceptions of the rule of law. I follow previous literature on the subject and expect countries with high levels of EF to exhibit low rule-of-law scores relative to countries with more ethnic homogeneity. I use Alesina and colleagues' EF variable from their 2003 data set. Alesina and colleagues calculate the probability that two randomly selected individuals in a country belong to the same ethnic group. I use data from 2003; Roeder (2001) demonstrates that EF does not change quickly. The mean EF score for countries in my data set is 0.419 and the standard deviation is 0.16 . Bolivia features the highest score, at 0.740, and Haiti, at 0.095, has the lowest.

\section{Model Specification and Estimation}

I use a fixed-effects model to estimate the relationship among political, economic, and social variables and perceived rule of law in Latin America. I estimate several models using different specifications and estimation techniques, but the primary model uses cross-sectional, time series regression with fixed effects. Table 1 presents the results of estimation using this technique, whereas the section "Robustness Checks" describes the complementary models.

\section{RESULTS AND DISCUSSION}

My estimates provide evidence for a strong, positive, statistically significant relationship between effective political constraints on authority and perceived rule of law. As hypothesized, high levels of political constraints are associated with high levels of the rule of law. I estimate that a 1.128 increase in rule-of-law scores follows a one-unit increase in political constraints scores. This increase is much larger than one could expect in reality because no country in my data set moves from a score of 0 to 1 in one year. The mean annual change in the data is 0.06 and the SD of the change is 0.12. Many countries in the data set exhibit annual shifts beyond two SDs in a given year, but these years are the exception, not the 
Table 1 Fixed-effects estimates of political constraints and the rule of law in Latin America, 1996-2012

\begin{tabular}{lc}
\hline \multicolumn{1}{c}{ Variable } & Coefficient (SE) \\
\hline Political constraints & $1.306(0.014)^{* *}$ \\
Per capita GDP, PPP (logged) & $5.592(0.015)^{* *}$ \\
Freedom House political rights score & $-0.117(0.052)^{*}$ \\
Party orientation & $0.108(0.047)^{*}$ \\
Ethnic fractionalization & $-0.364(0.012)^{* *}$ \\
Constant & $-0.916(0.006)^{* *}$ \\
\hline$N$ & 20 \\
Observations & 280 \\
F & 22.85 \\
Prob. $>$ F & 0.00 \\
$\mathrm{R}^{2}$ (overall) & 0.65 \\
\hline
\end{tabular}

Note: Standard errors are robust to autocorrelation and heteroskedasticity. ${ }^{*} p<.05 ;{ }^{* *} p<.01$.

rule. The shifts in the variable POLCON that one could reasonably expect are then between 0.06 and 0.30 . Corresponding estimated increases in rule of law scores are then only 0.08 for a mean POLCON shift, 0.24 for a one SD POLCON increase, and 0.39 for a two SD POLCON increase, holding all other variables constant at their means. An increase of two SDs in POLCON, indicating a large relative increase in constraints on politicians, generates an estimated shift in rule-of-law scores approximately equivalent to moving from Paraguay, with a 2012 rule-oflaw score of -0.87 , to Mexico, with a score of -0.56 , in one year. This difference is important-Mexico consistently ranks ahead of Paraguay on other governance indicators such as corruption, and on measures of state capacity and efficacy (World Bank 2015). ${ }^{9}$ This example is illustrative but not exact; the predicted rule-of-law scores for these countries depend on estimates at the means of all of the independent variables-Paraguay and Mexico vary on many dimensions other than the political institutions in place and the policy preferences of their elected officials. These estimates only suggest that, on average, shifts in a country's political constraints in a given year are associated with changes in perceived rule of law from both statistical and practical standpoints. Furthermore, several seemingly small annual increases in political constraints could add up to large estimated changes in the rule of law over a time frame of two to five years.

My results are similar to those of Andrews and Montinola (2004) in this area, only my data set allows me to test a wide variety of additional hypotheses over a much longer time frame. My results are also in line with previous scholarship on credible commitment and the rule of law with regard to the central role that constraints on authority play for credibility (North and Weingast 1989; Keefer and Stasavage 2003; Henisz 2000; Barro and Gordon 1983). However, my findings run counter to the conventional wisdom among those who study Latin American politics that legislative deadlock results in predominantly negative economic and

9. The mean standard error for the World Bank's rule-of-law scores is 0.135. 
political outcomes for countries (Linz 1994; Ames 2009; Cheibub 2002). My results are also the opposite of some scholarship (e.g., Frye 2002, 2010) maligning political polarization in general. Deadlock may still undermine governments' abilities to generate necessary reforms or take rapid action to resolve crises. Yet for my data set at least, effective constraints on policy making carry the silver lining of improving commitments to the rule of law.

The results of my estimation also provide evidence for other important arguments. The Freedom House measure of political rights, serving as a proxy for practical experience with governance in several different areas, is also a positive determinant of perceived rule of law in my model, similar to the theoretical and empirical arguments in Diamond (1996, 1999), O'Donnell (2001, 2004), Olken (2008), Keefer and Khemani (2005), Maravall and Przeworski (2003), Zakaria (2007), Gehlbach and Keefer (2011), and Montinola, Qian, and Weingast (1995)..$^{10}$ A one-unit increase in the FH score, indicating a country becoming "less free," results in an estimated decrease of 0.12 in the rule of law. This suggests that, on average, increases in democracy lead to improvements in the rule of law, even if some individual countries can make credible commitments to property rights outside of democratic boundaries, as in Chile under Pinochet (Barros 2003). Yet the mean shifts of FH scores are small: 0.35 per year, with an SD of 0.11 . This means even a rare two-SD shift in the FH score does not generate as much of a change in rule of law scores as a mean POLCON shift. Furthermore, my results demonstrate that the partisan political orientation of policy makers also matters for assessments of the rule of law in Latin America: moving from a leftist to a right-wing president increases the rule of law by an estimated 0.22 points, controlling for other factors in the model. This is less than the impact of the mean POLCON change on the rule of law, but it does occur more frequently in the data than a two-SD change in the Freedom House score. I explore this relationship further and present the results of estimation using an interaction term pairing POLCON with the party orientation variable in table 1c of the online appendix. ${ }^{11}$ Estimates of the rule of law are highest for countries with low POLCON scores and right-wing presidents, followed by countries with high POLCON scores and right-wing presidents, countries with high POLCON scores and left-wing presidents, and then countries with low POLCON scores and left-wing presidents. These results show a strong conditional influence of political constraints depending on whether a president is on the political left versus the right. They suggest that those evaluating the rule of law prefer unconstrained right-wing presidents but constrained left-wing presidents.

Next, I find that increases in GDP per capita (logged, PPP) also result in improved rule-of-law scores. I estimate that a 1 percent change in GDP per capita leads to a 0.06 increase in rule-of-law scores. This estimate reflects a powerful relationship between economic growth and the rule of law: a country beginning

10. I also present a model using a country's polity score, which measures different aspects of democracy, perhaps more in keeping with my theoretical arguments than the Freedom House score in table $1 \mathrm{~b}$ of the online appendix. Polity is a statistically significant determinant of the rule of law, and the coefficients on the other variables change very little.

11. The appendix is available on my website, at http://sps.boisestate.edu/politicalscience/faculty/ mike-touchton/. 
from the mean GDP per capita of $\$ 6,165$ and growing at a 3 percent rate over a decade could be expected to increase its rule-of-law score by 2.04 , all else equal. Such a whopping increase represents the approximate equivalent of moving from Cuba (-0.64) to Chile (1.37). In terms of potential for improvements in the rule of law, GDP growth thus provides the greatest long-term opportunities of any variable in my data set. The relationship between economic growth and the perception of rule of law offers powerful evidence in favor of modernization theory à la Lipset (1959), Przeworski (2000), and Boix (2011). A decade's worth of sustained economic growth is relatively rare in Latin America, but my estimates imply that substantial improvements in rule-of-law perceptions would follow such growth if countries could achieve it.

Finally, greater ethnic fractionalization is associated with lower rule-of-law scores in all models, which is consistent with Easterly and Levine (1997), Knack and Keefer (1997), La Porta and colleagues (1999), Habyarimana and colleagues (2007), Campos, Saleh, and Kuzeyev (2011), and Touchton (2013). The coefficient for EF is large, but EF is stable and changes are rare. EF is commonly and powerfully associated with the rule of law, but it changes so slowly as to be practically irrelevant in the short term compared to the other independent variables in some senses. Nevertheless, policies to mitigate the negative impact of EF on the rule of law could be fruitful and merit exploration in ethnically heterogeneous countries.

\section{ROBUSTNESS CHECKS}

My first robustness checks are technical. I estimate several different models of perceived rule of law to account for potential endogenous regressors. First, I supplement my fixed-effects model with a similar fixed-effects model but with a lagged dependent variable (table $1 c$ in the online appendix). Then I present a dynamic panel model from Arellano and Bond $(1988,1991)$ of rule-of-law perceptions to account for endogeneity and relatively time-invariant rule-of-law scores (table 1d). Finally, I present estimates from another GMM model, but with traditional instruments rather than lags of the independent variables (table 1c). Coefficients for POLCON and GDP per capita are smaller in these models, but both variables remain statistically significant in all of them and in the same direction as in the primary model. I include a full discussion of these models and diagnostics associated with them in the online appendix.

My next robustness check is theoretical. In many ways, rule-of-law perceptions are conceptually similar to POLCON, my primary independent variable. Constrained government sends a signal that all actors will have a relatively harder time undermining existing laws, but constrained government may reflect the rule of law and not act directly on the rule of law itself. Viewed in this light, effective political constraints do not influence the rule of law. Rather, they are the rule of law. It would therefore be surprising not to find statistical connections between POLCON and perceived rule of law, even while accounting for potentially endogenous relationships through statistical techniques. However, if political constraints are connected to perceived rule of law and rule-of-law perceptions 
Table 2 Fixed-effects estimates of political constraints and gross fixed capital formation (per capita, logged) in Latin America, 1996-2012

\begin{tabular}{lc}
\hline \multicolumn{1}{c}{ Variable } & Coefficient (SE) \\
\hline Political constraints & $0.557(0.015)^{* *}$ \\
Change in global GDP (\%) & $0.392(0.003)^{* *}$ \\
Freedom House political rights score & $-0.068(0.017)^{* *}$ \\
Party orientation & $0.156(0.024)^{*}$ \\
Ethnic fractionalization & $-0.217(0.040)^{* * *}$ \\
Leadership stability & $-0.034(0.018)^{*}$ \\
Trade openness & $0.005(0.002)^{*}$ \\
Constant & $0.219(0.013)^{* *}$ \\
\hline$N$ & 20 \\
Observations & 280 \\
F & 18.72 \\
Prob. > F & 0.00 \\
$\mathrm{R}^{2}$ (overall) & 0.51 \\
\hline
\end{tabular}

Note: Standard errors are robust to autocorrelation and heteroskedasticity. ${ }^{*} p<.05 ;{ }^{* *} p<.01$.

are connected to investment, then POLCON should also influence investment. Attempting to increase investment by constraining government and improving rule-of-law perceptions will not work if POLCON is unrelated to investment. A lack of connection here would also imply a gap between actual rule of law, which could still be very important for investment, and perceived rule of law, which would not be. I take steps to resolve this issue by estimating a fixed-effects model of gross fixed-capital formation (GFCF) in Latin America. Table 2 presents the results of estimation using GFCF, a proxy for fixed investments from both domestic and international sources, as a dependent variable. ${ }^{12}$

The results in table 2 mirror those for the rule of law in table 1: increases in political constraints increase fixed investment, as do right-wing governments, improvements in democracy, economic growth, and trade openness. ${ }^{13}$ High levels of ethnic fractionalization and low turnover of leaders are associated with lower investment levels, on average.

\section{CONCLUSION}

I account for one of the defining characteristics of politics to model the rule of law: political institutions and the policy preferences of elected officials in those institutions. Elected officials and their incentives represent a potential missing link between institutions and credibility: my results demonstrate how the inter-

12. These data come from the UN Statistical Commission's National Accounts Database, at http:// unstats.un.org/unsd/snaama/Introduction.asp. I use the base $10 \log$ of the raw GFCF per capita (PPP) in my models, giving a mean of 3.79 and SD of 1.30 .

13. The online appendix contains a description of the new covariates along with several additional models to account for endogenous regressors, as with the perceived rule-of-law variables. I present these models in tables $2 \mathrm{a}-\mathrm{d}$ in that online appendix. 
ests of politicians operating within well-defined institutional channels improve rule-of-law perceptions. These officials may still hinder government progress on a number of fronts, but my research suggests that the same institutional and political factors detrimentally limiting government in some areas may benefit the public in other areas by increasing policy credibility.

These results hold important implications for both scholars and practitioners interested in promoting democracy and economic development. My findings demonstrate the relevance of practical incentives for politicians to constrain one another's behavior for economic development. Ultimately, politically and ideologically opposed politicians deploying institutional checks on government improve rule-of-law perceptions and increase fixed investments because these politicians have practical motives to exercise those checks and balances-not just constitutional opportunities to do so. Deadlock is not the only outcome constraining Latin American leaders: my results imply that fostering pluralism in government might provide the benefits of balance as well.

\section{REFERENCES}

Acemoglu, Daron, Simon Johnson, and James Robinson

2001 "The Colonial Origins of Comparative Development: An Empirical Investigation." American Economic Review 91 (5): 1369-1401.

Alesina, Alberto, Arnaud Devleeschauwer, William Easterly, Sergio Kurlat, and Romain

Wacziarg

2003 "Fractionalization." Journal of Economic Growth 8 (2): 155-194.

Ames, Barry

2009 The Deadlock of Democracy in Brazil. Ann Arbor: University of Michigan Press.

Andrews, Josephine, and Gabriela Montinola

2004 "Veto Players and the Rule of Law in Emerging Democracies." Comparative Political Studies 37 (1): 55-87.

Arellano, Manuel, and Stephen Bond

1988 Dynamic Panel Data Estimation Using PPD: A Guide for Users. London: Institute for Fiscal Studies.

1991 "Some Tests of Specification for Panel Data: Monte Carlo Evidence and an Application to Employment Equations." Review of Economic Studies 58:277-297.

Barro, Robert J., and David B. Gordon

1983 "Rules, Discretion, and Reputation in a Model of Monetary Policy." Journal of Monetary Economics 12 (1): 101-121.

Barros, Robert

2003 "Dictatorship and the Rule of Law: Rules and Military Power in Pinochet's Chile." In Democracy and the Rule of Law, edited by J. M. Maravall and A. Przeworski, 188223. Cambridge: Cambridge University Press.

Benoit, Kenneth, and Michael Laver

2006 Party Policy in Modern Democracies. Vol. 19. New York: Taylor and Francis.

Boix, Carles

2011 "Democracy, Development, and the International System." American Political Science Review 105 (4): 809-828.

Brown, David, Michael Touchton, and Andrew Whitford

2011 "Political Polarization as a Constraint on Corruption: A Cross-National Comparison." World Development 39 (9): 1516-1529.

Budge, Ian

2001 Mapping Policy Preferences: Estimates for Parties, Electors, and Governments, 1945-1998. Vol. 1. Oxford: Oxford University Press. 
Campos, Nauro, Ahmad Saleh, and Vitaliy Kuzeyev

2011 "Dynamic Ethnic Fractionalization and Economic Growth." Journal of International Trade and Economic Development 20 (2): 129-152.

Cerqueti, Roy, Raffaella Coppier, and Gustavo Piga

2012 "Corruption, Growth and Ethnic Fractionalization: A Theoretical Model." Journal of Economics 106 (2): 153-181.

Charron, Nathan

2009 "Government Quality and Vertical Power-Sharing in Fractionalized States." Publius: The Journal of Federalism 39 (4): 585-605.

Chavez, Rebecca Bill

2004 The Rule of Law in Nascent Democracies: Judicial Politics in Argentina. Palo Alto, CA: Stanford University Press.

Cheibub, José Antonio

2002 "Minority Governments, Deadlock Situations, and the Survival of Presidential Democracies." Comparative Political Studies 35 (3): 284-312.

Coase, Ronald

1960 "The Problem of Social Cost." Journal of Law and Economics 3:1.

Demsetz, Harold

1967 "Toward a Theory of Property Rights." Law and Economics 1:341-353.

De Soto, Hernando

2003 The Mystery of Capital: Why Capitalism Triumphs in the West and Fails Everywhere Else. New York: Basic Books.

Diamond, Larry

1996 "Democracy in Latin America: Degrees, Illusions, and Directions for Consolidation." In Beyond Sovereignty: Collectively Defending Democracy in the Americas, edited by T. Farer, 52-107. Baltimore: Johns Hopkins University Press.

1999 (ed.) Democracy in Developing Countries: Latin America. 2nd ed. Boulder, CO: Lynne Rienner.

Djankov, Simeon, Rafael La Porta, Florencio López-de-Silanes, and Andrei Shleifer

2002 "Courts: The Lex Mundi Project." Discussion Paper No. 3344. Washington, DC: Center for Economic Policy and Research.

Easterly, William, and Ross Levine

1997 "Africa's Growth Tragedy: Policies and Ethnic Divisions." Quarterly Journal of Economics 112 (4): 1203-1250.

Foweraker, Joe, and Roman Krznaric

2002 "The Uneven Performance of Third Wave Democracies: Electoral Politics and the Imperfect Rule of Law in Latin America." Latin American Politics and Society 44 (3): 29-60.

Frye, Timothy

2002 "The Perils of Polarization: Economic Performance in the Postcommunist World." World Politics 54 (3): 308-337.

2010 Building States and Markets after Communism: The Perils of Polarized Democracy. New York: Cambridge University Press.

Garay, Urbi, and Maximiliano González

2008 "Corporate Governance and Firm Value: The Case of Venezuela." Corporate Governance: An International Review 16 (3): 194-209.

Gehlbach, Scott, and Philip Keefer

2011 "Investment without Democracy: Ruling-Party Institutionalization and Credible Commitment in Autocracies." Journal of Comparative Economics 39 (2): 123-139.

Glaeser, Edward, Rafael La Porta, Florencio Lopez de Silanes, and Andrei Shleifer 2004 “Do Institutions Cause Growth?" Journal of Economic Growth 9 (3): 271-303.

Haber, Stephen, Armando Razo, and Noel Maurer

2003 The Politics of Property Rights: Political Instability, Credible Commitments and Economic Growth in Mexico, 1876-1929. New York: Cambridge University Press.

Habyarimana, James, Macartan Humphreys, Daniel Posner, and Jeremy Weinstein

2007 "Why Does Ethnic Diversity Undermine Public Goods Provision?" American Political Science Review 101 (4): 709-725. 


\section{Latin American Research Review}

Haggard, Stephen, Andrew MacIntyre, and Lydia Tiede

2008 "The Rule of Law and Economic Development." Annual Review of Political Science 11:205-234.

Haggard, Stephen, and Lydia Tiede

2011 "The Rule of Law and Economic Growth: Where Are We?" World Development 9 (5): 673-685.

Henisz, Witold

2000 "The Institutional Environment for Economic Growth." Economics and Politics 12:1-31.

2002 "The Institutional Environment for Infrastructure Investment." Industrial and Corporate Change 11 (2): 355-389.

Henisz, Witold, and Bennet Zelner

2007 "Measures of Political Risk." Working paper. Philadelphia: Wharton School, University of Pennsylvania.

Hicken, Allen, Shanker Satyanath, and Ernest Sergenti

2005 "Political Institutions and Economic Performance: The Effects of Accountability and Obstacles to Policy Change." American Journal of Political Science 49:897-907.

Hoff, Karla, and Joseph Stiglitz

2002 "After the Big Bang? Obstacles to the Emergence of the Rule of Law in PostCommunist Societies." Working Paper No. 9282. Cambridge, MA: National Bureau of Economic Research.

Kaufmann, Daniel, Aart Kraay, and Massimo Mastruzzi

2007a "Growth and Governance: A Rejoinder." Journal of Politics 69 (2): 570-572.

2007b "Growth and Governance: A Reply." Journal of Politics 69 (2): 555-562.

2007c "The Worldwide Governance Indicators Project: Answering the Critics." Policy Research Working Paper No. 4149. Washington, DC: World Bank.

Kaufmann, Daniel, Aart Kraay, and Pablo Zoido-Lobatón

1999 "Aggregating Governance Indicators." Policy Research Working Paper No. 2195. Washington, DC: World Bank.

Keefer, Philip

2004 "What Does Political Economy Tell Us about Economic Development and Vice Versa?" Annual Review of Political Science 7 (1): 247.

Keefer, Philip, and Stuti Khemani

2005 "Democracy, Public Expenditures and the Poor: Understanding the Political Incentives for Providing Public Services." World Bank Research Observer 20 (1): 1-27.

Keefer, Philip, and Stephen Knack

2002 "Polarization, Politics and Property Rights: Links between Inequality and Growth." Public Choice 11 (1-2): 127-154.

Keefer, Philip, and David Stasavage

2003 "The Limits of Delegation: Veto Players, Central Bank Independence, and the Credibility of Monetary Policy." American Political Science Review 97 (3): 407-423.

Klingemann, Hans-Dieter, Andrea Volkens, Ian Budge, Judith Bara, and Michael McDonald

2006 Mapping Policy Preferences II: Estimates for Parties, Electors, and Governments in Eastern Europe, European Union, and OECD 1990-2003. Oxford: Oxford University Press, 2006.

Knack, Stephen, and Philip Keefer

1995 Institutions and Economic Performance: Cross-Country Tests Using Alternative Institutional Measures." Economics and Politics 7:207-227.

1997 "Does Social Capital Have an Economic Payoff? A Cross-Country Investigation." Quarterly Journal of Economics 112 (4): 1251-1288.

Kunicová, Jana, and Susan Rose-Ackerman

2005 "Electoral Rules and Constitutional Structures as Constraints on Corruption." British Journal of Political Science 35 (4): 573-606.

Kurtz, Marcus, and Andrew Schrank

2007a "Growth and Governance: A Defense." Journal of Politics 69 (2): 563-569.

2007b "Growth and Governance: Models, Measures and Mechanisms." Journal of Politics 69 (2): 538-554. 
La Porta, Rafael, Florencio López-de-Silanes, and Andrei Shleifer

2008 "The Economic Consequences of Legal Origins." Journal of Economic Literature 46 (2): 285-332.

La Porta, Rafael, Florencio López-de-Silanes, Andrei Shleifer, and Robert Vishny

1999 "The Quality of Government." Journal of Law, Economics and Organization 15 (1): 222-279.

Lijphart, Arend

1999 Patterns of Democracy: Government Forms and Performance in Thirty-Six Countries. New Haven, CT: Yale University Press.

Linz, Juan

1994 "Presidential or Parliamentary Democracy: Does It Make a Difference?" In The Failure of Presidential Democracy: The Case of Latin America, edited by J. J. Linz and A. Valenzuela, 3-90. Baltimore: Johns Hopkins University Press.

Lipset, Seymour

1959 "Some Social Requisites of Democracy: Economic Development and Political Legitimacy." American Political Science Review 53 (1): 69-105.

Mainwaring, Scott

1993 "Presidentialism, Multipartism, and Democracy The Difficult Combination." Comparative Political Studies 26 (2): 198-228.

Maravall, Jose Maria, and Adam Przeworski, eds.

2003 Democracy and the Rule of Law. New York: Cambridge University Press.

Marshall, Monty G., Keith Jaggers, and Ted Robert Gurr

2002 Polity IV Project. College Park: Center for International Development and Conflict Management, University of Maryland, College Park.

Mauro, Paolo

1995 "Corruption and Growth." Quarterly Journal of Economics 110 (3): 681-712.

Méndez, Juan, Guillermo A. O'Donnell, and Paulo Sérgio Pinheiro, eds.

1999 The $\left(U_{n}\right)$ Rule of Law and the Underprivileged in Latin America. Notre Dame, IN: University of Notre Dame Press.

Miller, Laurel, and Robert Perito

2004 "Establishing the Rule of Law in Afghanistan." Special Report No. 117. Washington, DC: US Institute of Peace.

Montinola, Gabriela, Yingyi Qian, and Barry Weingast

1995 "Federalism, Chinese Style: The Political Basis for Economic Success in China." World Politics 48 (1): 50-81.

Munck, Gerardo

2009 Measuring Democracy. Baltimore: Johns Hopkins University Press.

North, Douglass C.

1990 Institutions, Institutional Change, and Economic Performance. New York: Cambridge University Press.

North, Douglass C., and Barry R. Weingast

1989 "Constitutions and Commitment: Evolution of the Institutions Governing Public Choice in Seventeenth-Century England." Journal of Economic History 49 (4): 803-832.

Nunn, Nathan

2008 "The Long-Term Effects of Africa's Slave Trades." Quarterly Journal of Economics 123 (1): 139-176.

O’Donnell, Guillermo

2001 "Democracy, Law and Comparative Politics." Studies in Comparative International Development 36 (1): 7-36.

2004 "Why the Rule of Law Matters." Journal of Democracy 15 (4): 32-46.

Olken, Benjamin A.

2008 "Direct Democracy and Local Public Goods: Evidence from a Field Experiment in Indonesia." Working Paper No. 14123. Cambridge, MA: National Bureau of Economic Research.

Peerenboom, Randall

2002 China's Long March toward Rule of Law. Cambridge: Cambridge University Press. 


\section{6}

Perito, Robert

2003 "Special Report: Establishing the Rule of Law in Iraq." Washington, DC: US Institute of Peace.

Persson, Torsten, and Guido Tabellini

2003 The Economic Effects of Constitutions. Cambridge, MA: MIT Press.

Przeworski, Adam, ed.

2000 Democracy and Development: Political Institutions and Well-Being in the World, 19501990. Cambridge: Cambridge University Press.

Roeder, Philip G.

2001 Ethnolinguistic Fractionalization (ELF) Indices, 1961 and 1985. San Diego: University of California-San Diego.

Schüler, Dana, and Julian Weisbrod

2010 "Ethnic Fractionalisation, Migration and Growth." Empirical Economics 39 (2): 457-486.

Stasavage, David

2002 "Credible Commitment in Early Modern Europe: North and Weingast Revisited." Journal of Law, Economics and Organization 18 (1): 155-186.

Stein, Kenneth

2011 "Exxon-Venezuela Arbitration Dispute: Next Steps and Impact on Future Investor-State Disputes under ICSID." Journal of World Energy Law and Business 4 (4): 380-389.

Tamanaha, Brian

2004 On the Rule of Law: History, Politics, Theory. New York: Cambridge University Press. Touchton, Michael

2013 "The Dangers of Diversity: Ethnic Fractionalization and the Rule of Law." Journal of Economics, Management and Financial Markets 1:20-40.

2014 "Trapping the Tigers: Regulation of Market Entry and the Rule of Law in SE Asia." Social Science Journal 52 (1): 8-21.

2015 "Who Commits to the Rule of Law? Constrained Government and Foreign Direct Investment in Postcommunist States." East European Politics 31 (4): 468-486.

Treisman, Daniel

2000 "The Causes of Corruption: A Cross-National Study." Journal of Public Economics 76 (3): 399-457.

Tsebelis, George

1995 "Decision Making in Political Systems: Veto Players in Presidentialism, Parliamentarism, Multicameralism and Multipartyism." British Journal of Political Science 25 (3): 289-325.

2002 Veto Players. Princeton, NJ: Princeton University Press.

Ugalde, Luis

2000 The Mexican Congress: Old Player, New Power. Washington, DC: Center for Strategic and International Studies.

Weingast, Barry

1997 "The Political Foundations of Democracy and the Rule of Law." American Political Science Review 91 (2): 245-263.

Woodberry, Robert

2012 "The Missionary Roots of Liberal Democracy." American Political Science Review 106 (2): 244-274.

World Bank

2015 World Development Indicators. Washington, DC: World Bank. http://data.worldbank .org/data-catalog/world-development-indicators.

Zakaria, Fareed

2007 The Future of Freedom: Illiberal Democracy at Home and Abroad. Rev. ed. New York: W. W. Norton. 